Ensino, Saúde e Ambiente-V11 (1), pp.59-86, Abril. 2018

\title{
REPRESENTAÇÕES SOCIAIS SOBRE O MEIO AMBIENTE DE ESTUDANTES DO ENSINO PROFISSIONALIZANTE NA AMAZÔNIA SUL- OCIDENTAL
}

\section{SOCIAL REPRESENTATIONS ON THE ENVIRONMENT OF VOCATIONAL EDUCATION STUDENTS IN THE SOUTHWEST AMAZON}

\author{
Renata Gomes de Abreu Freitas ${ }^{1}$, Rosane Moreira Silva de Meirelles ${ }^{2}$ \\ ${ }^{1}$ Docente do Instituto Federal do Acre/IFAC, renata.freitas@ifac.edu.br \\ ${ }^{2}$ Docente da Universidade do Estado do Rio de Janeiro/UERJ, rosanemeirelles@ gmail.com
}

\begin{abstract}
RESUMO
A educação ambiental tem como objeto a relação humana com o meio ambiente, o que pode favorecer a promoção de uma abordagem colaborativa e crítica das realidades socioambientais e uma compreensão contextualizada dos problemas que se apresentam. Este artigo apresenta os resultados de uma pesquisa que objetivou caracterizar a educação ambiental difundida na trajetória acadêmica de estudantes do ensino médio integrado à formação profissionalizante de um Instituto Federal de Educação, Ciência e Tecnologia localizado na Amazônia Sul-Ocidental e analisar suas representações acerca do meio ambiente e os problemas ambientais. Tratou-se de uma pesquisa de cunho qualitativo, para a qual se utilizaram três procedimentos para a coleta de dados: questionário, produção de desenhos temáticos e escolha livre de imagens representativas de meio ambiente. Usou-se como metodologia de interpretação dos dados a técnica do Discurso do Sujeito Coletivo (DSC). Como resultado, verificou-se que a educação ambiental esteve presente no transcorrer da formação dos estudantes, sendo registrada também na educação profissionalizante. Entretanto, verificou-se, que a Educação Ambiental ocorre restrita a algumas áreas do conhecimento, assim como reduzida a ações realizadas paralelamente às atividades curriculares. Cinco categorias de discurso indicaram em primeiro momento representações limitadas de meio ambiente, e duas categorias remetem-se a representações integradas de meio ambiente, uma vez que inserem elementos humanos no contexto representado, bem como demostram compreensão de que o ser humano se apropria da natureza e que o resultado dessa relação acontece em um contexto histórico-social. Com os resultados foi possível concluir que as representações dos sujeitos investigados quanto ao meio ambiente e os problemas ambientais assemelham-se com as tendências de educação ambiental escolar pelas quais perpassaram, explicitadas por meio das atividades registradas pelos estudantes. O método do Discurso do Sujeito Coletivo, demostrou eficiência no resgate das representações, revelando como os estudantes percebem e se relacionam com o meio ambiente e os problemas ambientais no cotidiano.
\end{abstract}

Palavras-chave: Educação ambiental, Representações sociais, Meio Ambiente, Educação Profissional

\section{ABSTRACT}

Environmental education has the human relationship with the environment as object, which may favor the promotion of a collaborative and critical approach to socioenvironmental realities, with a contextualized understanding of the problems that present themselves. This research presents the results of a study that aimed to characterize the environmental education disseminated in the academic trajectory of high school students integrated in the vocational training program of a Federal Institute 
of Education, Science and Technology located in the SouthWest Amazon, and analyze their representations on the environment and environmental problems. The study was a qualitative research using three procedures for data collection, namely the application of questionnaires, the production of thematic designs and the free choice of representative images of the environment. The technique of Collective Subject Discipline (CSD) was used as the data interpretation methodology. Environmental Education was present during student training and was also recorded during the vocational education. However, Environmental Education waspresent restricted to certain areas of knowledge, as well as reduced to actions carried out in parallel to curricular activities. Five discourse categories first indicated limited representations of the environment, and two categories referred to integrated representations of the environment, since they insert human elements into the represented context, as well as demonstrate understanding regarding the fact that human beings appropriate nature and that the result of this relationship occurs in a social historical context. With the results obtained herein, it was possible to conclude that the representations of the investigated subjects regarding the environment and environmental problems are similar to the tendencies of their school environmental education, made explicit through the student registered activities. The Collective Subject Discourse method was efficient regarding representations, revealing how students perceive the environment and environmental problems related to everyday life.

Key-words: Environmental education, Social representations, Environment, Professional education

\section{INTRODUÇÃO}

O século XX foi marcado pela acelerada industrialização, surgimento de novas tecnologias, mudanças substanciais nas comunicações globais e, também, pela explosão demográfica, promovendo uma profunda alteração na estrutura societária, ampliando significativamente as áreas urbanas e elevando a demanda pelos recursos naturais, o que tem ocorrido via incipiente planejamento e controle sobre os efeitos que geram sobre o meio ambiente (CATALÃO, 2009). Nessas circunstâncias, é vivido, nos dias atuais, um cenário de crise não somente ambiental como também social e política, o que Carvalho (2013) enfatiza ser uma crise instaurada a partir do modelo societário moderno. Como resultado, a sobrevivência do planeta está ameaçada à exaustão e ao aniquilamento dos bens naturais com a poluição das águas, por despejo de dejetos e resíduos contaminantes; do ar, pela emissão de gases tóxicos, perda da biodiversidade, empobrecimento e contaminação do solo, supressão da vegetação original e uso intensivo da terra. Além disso, convivemos com a desigualdade social em massa em diferentes regiões do planeta, resultando flagelos sociais tais como a fome, violência, proliferação e reincidência de doenças negligenciadas (FREITAS, PANZERI, MEIRELLES (2015). 
Diante desse cenário, a educação ambiental surge como um marco importante, pois apresenta potencial para orientar a formação de sujeitos sociais de pensamento crítico, com capacidade para analisar e se posicionar frente à degradação ambiental, observando a inter-relação entre processos naturais, sociais, econômicos e culturais que estão associados à crise civilizatória (LEFF, 2004). Ainda nesse sentido, a educação ambiental tem como objeto a relação humana com o meio ambiente, sendo, portanto, necessária para promover uma abordagem colaborativa e crítica das realidades socioambientais e, também, uma compreensão contextualizada dos problemas que se apresentam, buscando, portanto, soluções para reverter o quadro de degradação no qual o meio ambiente se encontra (SAUVÉ, 2005a).

No Brasil, a educação ambiental está regulamentada pela Lei Federal $N^{o}$ 9.795/99 que institui a Política Nacional de Educação Ambiental (PNEA) e, mais recentemente, pelas Diretrizes Curriculares Nacionais para a Educação Ambiental (DCNEA). De acordo com a legislação, todos os cidadãos têm direito a educação ambiental, portanto, esta é componente essencial e permanente da educação nacional, devendo estar presente em todos os níveis e modalidades do processo educativo, em caráter formal e não-formal.

Estudos teóricos demonstram que existem várias maneiras de se pensar e de praticar a educação ambiental, descrevendo várias tendências que as caracterizam. Lucie Sauvé (2005b) mapeou a existência de quinze correntes/vertentes diferentes de educação ambiental, sendo algumas de tradições mais antigas as quais foram dominantes nas primeiras décadas da educação ambiental e outras consideradas mais recentes, resultado de preocupações decorrentes do avanço da modernidade. Trabalhos e documentos, no Brasil, evidenciam também uma diversidade de correntes políticopedagógicas na educação ambiental, sendo uma das mais recentes a de Layrargues e Lima $(2011$, 2014), que mapeou três macrotendências como modelos políticopedagógicos para a Educação Ambiental, são elas: Conservacionista, Pragmática e Crítica. Conforme os autores, cada uma dessas macrotendências contemplam uma gama de outras tendências de posicionamentos semelhantes, o que pode estar associado à forma como os atores compreendem e se posicionam sobre o meio ambiente.

A Política Nacional de Educação Ambiental e os documentos que se desdobraram posteriormente apresentam orientações na perspectiva crítica de educação Ambiental, a tomar pelo enfoque humanista, democrático e participativo. A perspectiva 
transdisciplinar e problematizadora das questões ambientais também se encontra bem claras em tais documentos, via contextualização da realidade do educando, com fins de elaboração de uma concepção globalizante de meio ambiente (TORRES, 2010).

Nesse sentido, aqueles intencionados em intervir de forma mais eficaz na perspectiva do pensamento crítico e complexo devem, antes de qualquer ação em educação ambiental, compreender como os sujeitos apreendem o meio ambiente (REIGOTA, 2007). Tal consenso tem sido debatido pela comunidade científica a fim de compreender as visões, ideias, concepções, percepções e representações de diferentes grupos quanto ao meio ambiente, em busca de aporte para desenvolver estratégias com fins de implementação da educação ambiental crítica.

Reigota (2007), observando não haver um consenso, mesmo por especialistas de diversos campos científicos sobre o meio ambiente, supôs que este não possui um conceito definido, tratando-se, portanto, de uma representação social. Desse modo, discute que "a compreensão das diferentes representações deve ser tomada como base na negociação e solução das questões ambientais". Assim, orienta que qualquer prática de educação ambiental deve preceder às representações que os sujeitos envolvidos tenham sobre o meio ambiente. $\mathrm{O}$ autor destaca ainda que "a representação de meio ambiente propõe a discussão de hábitos, cultura, política, necessidades, atitudes e condutas do dia-a-dia” (REIGOTA, 2007 p. 28).

Dentre esses estudos, é possível citar o de Garrido e Meirelles (2014) que discutiu as percepções de meio ambiente de estudantes do ensino fundamental; o estudo de Cardoso, Frenedozo e Araújo (2015) que analisaram as concepções de meio ambiente de estudantes de licenciatura em ciências biológicas, bem como o estudo de Camargo (2008), que objetivou conhecer as representações sociais acerca do meio ambiente de moradores do entorno de uma unidade de conservação.

A partir desses e de outros estudos, é possível verificar de forma geral que os sujeitos apresentam diferenciadas formas de compreensão e posição a respeito do tema, os quais geralmente são apresentados em categorias. Grande parte das categorias manifestadas vislumbra representações de visão limitadas em contraposição às categorias mais integradas de meio ambiente. Conceituamos, aqui, meio ambiente limitado como aquele tomado como sinônimo de natureza, onde predominam elementos naturais em detrimento do ser humano e suas diferentes formas de manifestações. Em 
determinadas categorias, o ser humano aparece, no entanto, em uma relação pacífica, de contemplação ou de denúncia, quando é dado importante destaque aos problemas ambientais, porém dissociados de reflexão sobre a origem de suas causas. Quase sempre o meio ambiente é representado como sinônimo de fornecedor de recursos para a manutenção da humanidade, o que reflete uma visão antropocêntrica deste.

Por outro lado, representações de meio ambiente integrado, apresentam-se vinculadas à inserção do ser humano como elemento constituinte do meio ambiente, sendo as mudanças e os problemas do ambiente compreendidos como resultado do processo histórico de apropriação do ser humano à natureza medido pela organização socioeconômica.

Nesse sentido, o presente estudo apresenta como objetivo identificar representações relacionadas ao meio ambiente e aos problemas ambientais, traçando comparativos com a educação ambiental pela qual perpassaram educandos em suas trajetórias estudantis. Os sujeitos da pesquisa são estudantes do ensino médio integrado ao técnico (técnico informática) do Campus Rio Branco, unidade de ensino do Instituto Federal do Acre (IFAC).

\section{PERCURSO METODOLÓGICO}

A presente pesquisa foi autorizada pelo Comitê de Ética em Pesquisas da Fundação Oswaldo Cruz sob o Parecer 775.767 CAE: 31891214.1.00005248. Dentre as diferentes abordagens para análise das ideias sobre meio ambiente, definimos o arcabouço teórico-metodológico das representações sociais como referencial analítico. Segundo Arruda (2002), a teorização das representações sociais ocorreu no campo da psicologia social, em 1961, por Serge Moscovivi em sua obra La Psychanalyse, son image, son public. Este passou a utilizar o adjetivo "sociais" e não mais "coletivas" como originalmente foi proposto por Émile Durkheim e Lucien Lévy (MOSCOVICI, 2003; ALEXANDRE, 2004). Essa teoria foi aprofundada posteriormente a partir dos trabalhos de Denise Jodelet, que fez um estudo pioneiro sobre as representações sociais de pacientes com doenças mentais, contribuindo significativamente para a sistematização da mesma (SÁ 1998).

Desse modo, a partir dos anos 80 o conceito de representação social tornou-se solidificado e passou a ser amplamente usado como referência nos estudos de temas contemporâneos, principalmente na saúde, educação, didática e meio ambiente (ARRUDA, 2002). Conforme Jodelet (2002), a representação social é a expressão de alguém (sujeito) em relação a alguma coisa (objeto), podendo ser elementos 
informativos, cognitivos, ideológicos, normativos, crenças, valores, atitudes, opiniões, imagens, dentre outros (JODELET, p. 09).

Ainda segundo a autora, a representação social trata-se de um modo próprio de se pensar (senso comum), o qual tem papel crucial no desvelamento sobre o estado da realidade, ou seja, na descrição e análise do fenômeno estudado para explicar suas dimensões, formas, processos e funcionamento.

Nas palavras de Minayo (2008), as representações sociais são "uma mistura das ideias das elites, das grandes massas e também das filosofias correntes, e expressão das contradições vividas no plano das relações sociais de produção", tornando-a campo de importante interesse para compreender certas posições frente a determinados objetos sociais.

Conforme Busato et al (2012), representações referentes ao meio ambiente são importantes para a formulação de projetos sociais e educacionais, na medida em que permitem compreender como sujeitos envolvidos percebem e se relacionam como o meio ambiente.

Com base no objetivo proposto por esta pesquisa, elegemos como opção metodológica a pesquisa de abordagem qualitativa, que em linhas gerais procura compreender um determinado fenômeno por meio de descrições, análises e interpretações sem necessariamente lançar mão de tratamentos estatísticos e regras rígidas.

O estudo envolveu três procedimentos coleta de dados: a) Produção de Desenho Temático; b) Questionário semi-estruturado; e c) escolha de imagens representativas de categorias de meio ambiente.

Com o procedimento "a" obteve-se desenhos que retratavam o meio ambiente, acompanhados de descrições que vislumbravam os símbolos dispostos no conjunto da ilustração reproduzida pelos estudantes. A técnica de desenho temático foi proposta por Tania Aiello-Vaisberg (1997), utilizando-os em pesquisas clínicas em psicologia. Segundo a autora, esse procedimento envolve arte e técnica firmemente fundamentadas no método psicanalista. Assim como no desenho-estória, o procedimento não deve preceder de nenhum estímulo, consistindo na solicitação da elaboração de um desenho especificado em termos temáticos (MEDEIROS, 2014). Posteriormente, pede-se para que o pesquisado crie uma estória para o desenho produzido. 
O questionário utilizado para coleta de dados (procedimento "b") foi organizado em 10 questões, solicitando, inicialmente, informações sobre como foi a abordagem da temática ambiental na trajetória acadêmica dos estudantes. Um segundo grupo de questões versou sobre os problemas ambientais, suas causas, bem como a relação destes com a saúde humana. Um último grupo de questões teve como objetivo identificar suas representações acerca do meio ambiente.

As imagens utilizadas no procedimento "c" para coleta de dados foram produzidas com base nas categorias apresentadas por Rodrigues e Malafaia (2009) nas proposições de Reigota (2007), Brügger (2004), Tamaio (2002) e Fontana et al (2002), porém foram inseridos elementos da paisagem Amazônica, para trazer as imagens o mais próximo possível ao contexto dos estudantes (Quadro 1). Houve uma readequação na categoria "Romântica" de meio ambiente descrita por Tamaio (2002), pois os desenhos produzidos por um grupo de alunos da mesma instituição e mesmo nível de ensino, coletados em uma experiência piloto, demostraram a inserção do ser humano, porém numa posição pacífica de contemplação, demostrando um meio ambiente "harmônico/idealizado" (imagem A, figura 1).

Quadro 1: Categorias de meio ambiente adotadas na coleta de dados do procedimento "c"

\begin{tabular}{|l|l|}
\hline \multicolumn{1}{|c|}{ CATEGORIAS } & \multicolumn{1}{c|}{ DESCRIÇÃO } \\
\hline A. HARMÔNICO/ & $\begin{array}{l}\text { Aponta a grandiosidade da natureza, sempre harmônica, enaltecida, } \\
\text { maravilhosa, com equilíbrio e beleza estética. O ser humano está } \\
\text { inserido neste processo, porém de maneira pacífica, de contemplação e } \\
\text { usufruto sem haver interferência sobre a paisagem e os recursos } \\
\text { naturais. }\end{array}$ \\
\hline \multirow{3}{*}{ B. REDUCIONISTA } & $\begin{array}{l}\text { Traz a ideia de que o meio ambiente refere-se estritamente aos aspectos } \\
\text { físicos naturais, como a água, o ar, o solo, as rochas, a fauna e a flora, } \\
\text { excluindo o ser humano e todas as suas produções. Diferentemente da } \\
\text { categoria "romântica", não proclama o enaltecimento da natureza. }\end{array}$ \\
\hline B. UTILITARISTA & $\begin{array}{l}\text { Esta postura, também dualística, interpreta a natureza como } \\
\text { fornecedora de vida ao ser humano, entendendo-a como fonte de } \\
\text { recursos para o homem. Apresenta uma leitura antropocêntrica. }\end{array}$ \\
\hline C. ABRANGENTE & $\begin{array}{l}\text { Define o meio ambiente de uma forma mais ampla e complexa. } \\
\text { Abrange uma totalidade que inclui os aspectos naturais e os resultantes } \\
\text { das atividades humanas, sendo assim, o resultado da interação de } \\
\text { fatores biológicos, físicos, econômicos e culturais. }\end{array}$ \\
\hline D e E. SOCIOAMBIENTAL & $\begin{array}{l}\text { Desenvolve uma abordagem histórico-cultural. Essa leitura apresenta o } \\
\text { homem e a paisagem construída como elementos constitutivos da } \\
\text { natureza. Postula uma compreensão de que o homem apropria-se da } \\
\text { natureza e que o resultado dessa ação foi gerado e construído no } \\
\text { processo histórico. Muitas vezes o homem surge como destruidor e } \\
\text { responsável pela degradação ambiental. }\end{array}$ \\
\hline
\end{tabular}

Fonte: categorias 2 a 5 Rodrigues e Malafaia (2009) com base nas proposições de Reigota (2007),

Brügger (2004), Tamaio (2002) e Fontana et al (2002), categoria 1 adaptada pelas autoras

Uma vez que ocorreram alguns padrões de desenhos obtidos na coleta piloto que remetiam à representação de meio ambiente socioambiental, foram elaboradas duas 
imagens para contemplar a referida categoria. A primeira foi composta por três outras imagens, demostrando um ambiente natural em transformação (imagem E, figura 1). A segunda reúne um conjunto de paisagens, aparecendo tanto ambientes naturalizados quando humanizados, representados por atividades de transformação (imagem F, figura $1)$.

Figura 1: Imagens de categorias de meio ambiente utilizadas no procedimento "c"

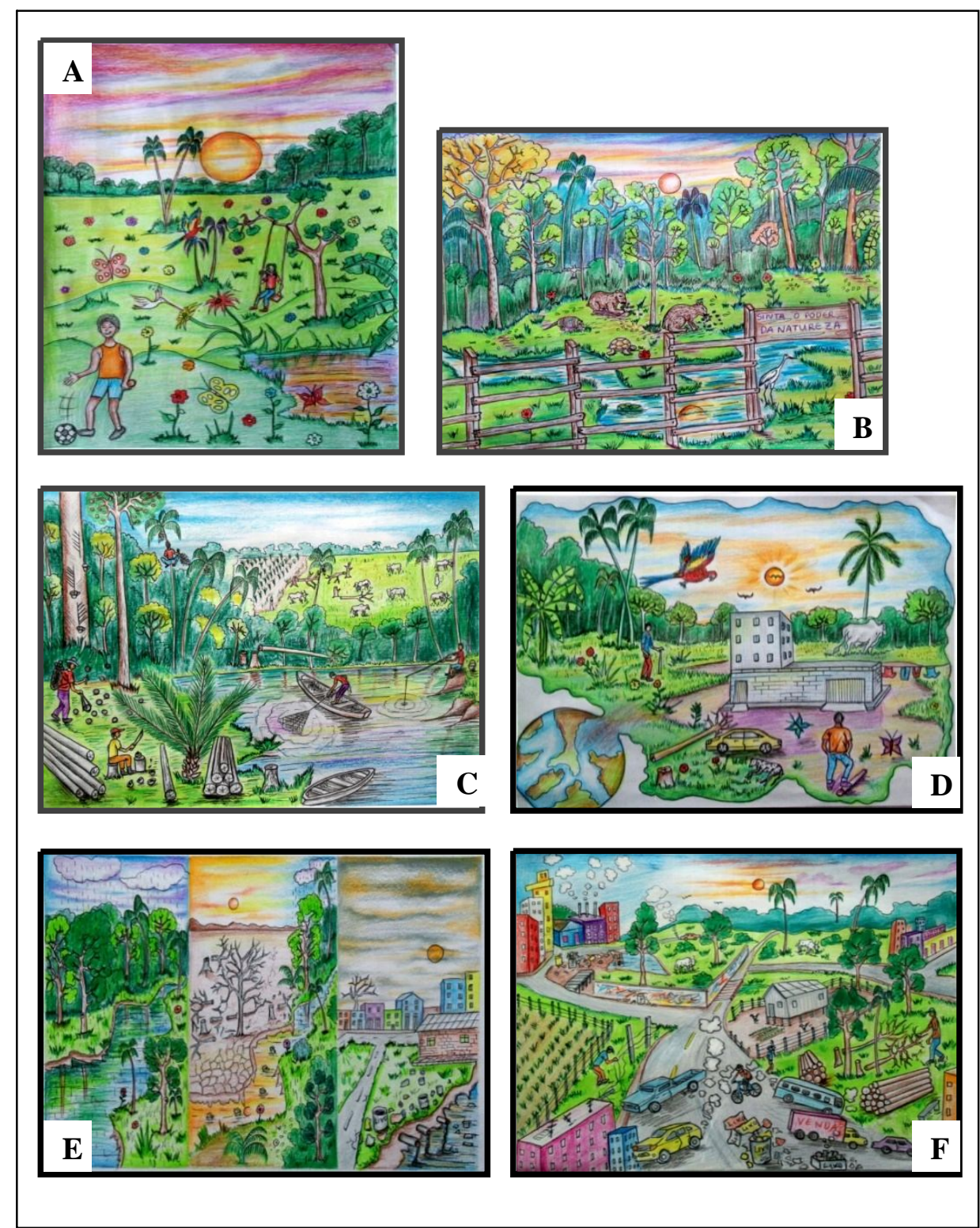

Fonte: produzidas pelo artista plástico Ueliton Santana sob a orientação das autoras

Para a coleta de dados utilizando esse último procedimento, as imagens impressas em formato banner $(60 \times 60 \mathrm{~cm})$, foram dispostas em sala de aula com a 
seguinte orientação: Observe as seis imagens expostas e indique aquela que você considera que melhor representa o meio ambiente. Em seguida, apresente uma justificativa por que esta imagem é a que melhor pode representar o meio ambiente em sua opinião.

Os dados textuais obtidos foram interpretados utilizando-se a técnica do Discurso do Sujeito Coletivo (DSC) elaborada por Lefévre e Lefévre (2005). A referida técnica se propõe em resgatar os discursos semelhantes dos sujeitos investigados, sendo possível construir um discurso único que revele como as pessoas pensam, atribuem sentidos e manifestam posicionamentos sobre determinado tema/assunto. Para a obtenção do DSC sobre o meio ambiente e sobre os problemas ambientais, os dados textuais foram elaborados em mapas denominados Instrumentos de Análise do Discurso (IAD), as expressões-chaves, ideias centrais e ancoragens.

As expressões-chaves compreendem descrições literais dos depoimentos que revelam a essência do que o sujeito pensa sobre o tema investigado, ou seja, o conteúdo das representações. A partir desses recortes que compreendem falas significativas, identificam-se as ideias centrais que são expressões linguísticas que revelam de maneira mais abreviada o sentido dos depoimentos. A ancoragem refere-se ao que sustenta o pensamento dos sujeitos investigados, sendo expressa por meio de alguma teoria, ideologia ou crença (DUARTE, MAMEDE e ANDRADE, 2009).

\section{RESULTADOS E DISCUSSÃO}

\section{A EDUCAÇÃO AMBIENTAL NA TRAJETÓRIA ESCOLAR DOS ESTUDANTES}

Participaram do estudo 93 estudantes dos 111 matriculados no ensino médio integrado à formação profissionalizante do Campus Rio Branco, unidade de ensino pertencente ao Instituto Federal de Educação, Ciência e Tecnologia do Acre (IFAC). Esses estudantes ingressaram na instituição entre os anos de 2012 e 2015, com faixa etária entre 14 e 20 anos, sendo 32 do sexo feminino e 61 do sexo masculino.

No que se refere às ações de educação ambiental vivenciadas no decorrer da vida acadêmica, 68 estudantes afirmaram ter participado pelo menos de uma atividade que se referia a esse tema, enquanto 25 afirmaram nunca terem participado de alguma atividade referente ao meio ambiente. As atividades de educação ambiental informadas 
pelos estudantes como realizadas no decorrer de sua trajetória acadêmica foram agrupadas em quatro categorias: (1) Participação em eventos (Semana do Meio Ambiente, Dia da água, Dia da Amazônia, palestras de conscientização, dentre outras); (2) Projetos e ações práticas (produção de maquete, reciclagem, plantio de mudas e limpeza do quintal da escola e de ambientes de visitação); (3) Visitas/passeios (parques e hortos florestais); (4) Atividades curriculares (trabalho de pesquisa com temas diversos: água, desmatamento, queimadas, poluição, lixo dentre outros).

Ainda de acordo com os estudantes, tais atividades, as quais consideram tratar-se de educação ambiental, ou que remetem às questões ambientais, foram mais abordadas/tratadas em suas trajetórias escolares, primeiramente, pela disciplina de geografia, seguida por ciências e Biologia, apresentando-se de maneira mais secundária as disciplinas de química, sociologia, física, artes e história (Figura 2).

Figura 2: Áreas de conhecimento que, segundo os estudantes, mais abordaram as questões ambientais na trajetória escolar.

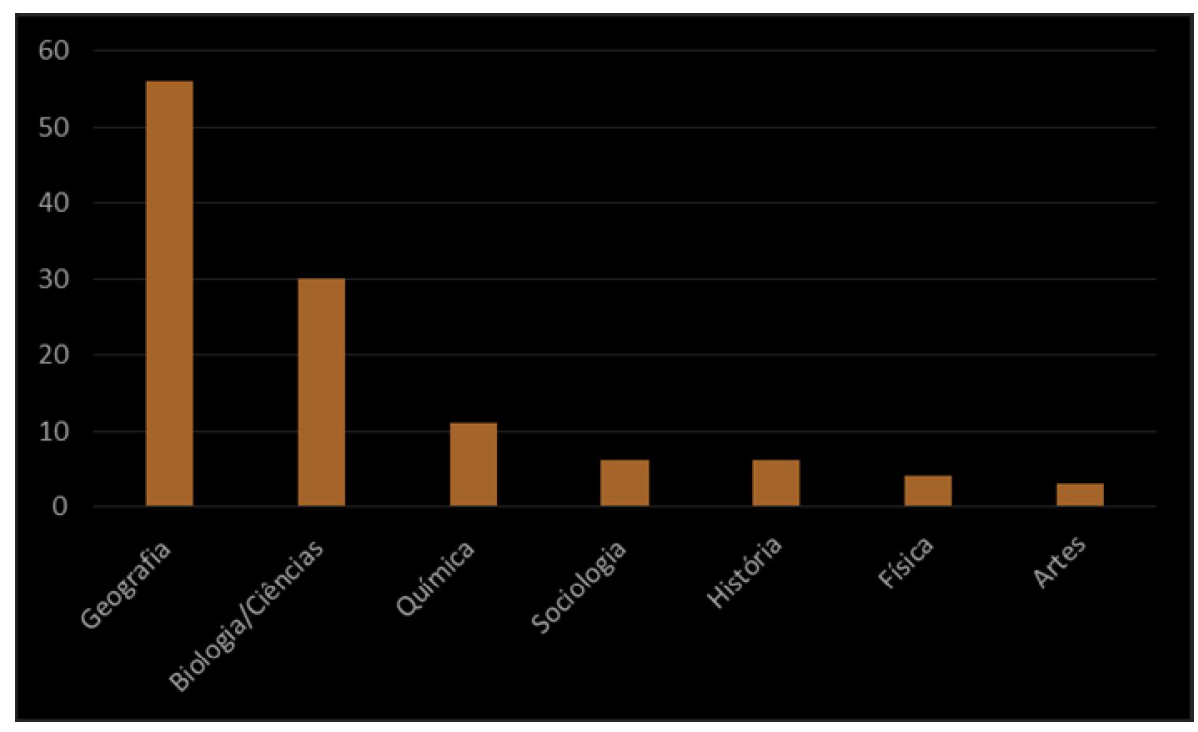

Fonte: elaborado pelas autoras

A partir dos resultados explicitados, é possível constatar que ações educacionais referentes ao meio ambiente foram/estão ocorrendo no desenvolvimento da formação dos estudantes investigados. Esses dados corroboram com o Censo Escolar de 2001 e 2004, nos quais foi inserida uma questão sobre a ocorrência da educação ambiental nos estabelecimentos de ensino. Veiga, Amorin e Blanco Cossio (2005) relataram que houve significativos números de estabelecimentos de ensino que declararam trabalhar com a temática ambiental (2001: 61,2\% e 2004: 94\%). 
Um estudo posterior realizado pelo MEC/INEP intitulado: "O que fazem as escolas que dizem que fazem Educação Ambiental?", apontam que na região Norte a educação ambiental parece ter sido implantada mais recentemente que na região Sudeste, no entanto, apresenta características semelhantes, como, por exemplo, as ações nas escolas, em grande parte, ocorrem por inciativa de um professor ou um grupo de professores, e que estes, geralmente, são aqueles que mais se identificam com a causa ambiental (TRAJBER, MENDOÇA, 2006). As ações geralmente são desenvolvidas em formato de projetos, ou atividades alusivas às datas comemorativas, envolvendo as áreas de Geografia e Ciências, os quais apresentam tratamentos mais específicos quanto aos aspectos físicos e naturais (TOZONI-REIS et al, 2012).

Nossos resultados não diferem do cenário observado a partir desse panorama da educação ambiental escolar para o ensino fundamental, uma vez que as atividades referentes ao meio ambiente não fomentam a interdisciplinaridade, estando sob a liderança das áreas de Geografia, Ciências e Biologia, tanto em ciclos de ensino anteriores quanto no âmbito do IFAC.

Tozoni-Reis e colaboradores (2012), ao fazerem uma análise da educação ambiental praticada em ambiente escolar, consideram que há uma tendência em reduzir a educação ambiental apenas ao ensino de ciências. Todavia, um aspecto que chama atenção em nosso estudo é o fato de nenhum componente curricular do eixo profissionalizante, ao qual pertencem os estudantes, (Comunicação e Informação) ter sido mencionado como integrador das ações ambientais revelando, assim, incoerência com princípios dispostos na PNEA, quanto ao caráter interdisciplinar da abordagem ambiental.

Tozoni-Reis e Campos (2015) consideram que a educação ambiental no ensino básico tem acontecido de maneira muito frágil e que, em parte, isso decorre da própria formação dos docentes. Como citado pelas autoras, os cursos de formação de professores, incluindo as licenciaturas, ainda não integraram em seus currículos de formação a abordagem ambiental. Nas escolas profissionalizantes, como é o caso do IFAC, a possibilidade de não se adotar a abordagem ambiental pode ser ainda maior, tendo em vista que grande parte do corpo docente é composta por bacharéis e tecnólogos que atuam no eixo profissionalizante, os quais não obtiveram ou não passaram por uma complementação pedagógica.

Por outro lado, as atividades mencionadas pelos estudantes que demonstram como o tema meio ambiente é tratado, em sua maioria, caracterizarem-se como 
pontuais, a exemplo dos mutirões de retirada de lixo na escola, ou nos lugares de visitação (parques ambientais), atividades de reciclagem de material e participação em eventos de conscientização ambiental. De acordo com Bizerril (2001), atividades como essas, e outras semelhantes, são desenvolvidas com fins de cumprimento da educação ambiental nas escolas e que normalmente ocorrem desvinculadas de uma proposta pedagógica contínua e interdisciplinar.

Nesses termos, compreendemos que as atividades vivenciadas pelos estudantes do IFAC, ao longo de suas trajetórias, não apresentam possibilidades concretas de subsidiar a educação ambiental em uma perspectiva crítica, tendo em vista que são balizadas por ações práticas isoladas ou ilustrativas sem conteúdos que realmente abordem a temática sob a perspectiva da complexidade intrínseca às questões ambientais da modernidade.

A ausência da criticidade, ou melhor, de diálogo que desvele as questões ambientais e que trate de seus fundamentos, torna as ações de educação ambiental inócuas e, portanto, não apresentam capacidade de instrumentalizar os educandos para que possam pensar sobre as questões ambientais na sua totalidade (LEROY, PACHECO, 2011). Nesses termos, consideramos que ações de educação ambiental, como as apontadas pelos estudantes neste estudo, em grande proporção, são conduzidas de forma a mascarar ou ser conivente com o modelo econômico vigente, o qual é responsável pela sociedade altamente consumista e descomprometida com a qualidade e justiça socioambiental (LOUREIRO, 2004, TOZONI-REIS, 2008).

\section{REPRESENTAÇÕES DE MEIO AMBIENTE E DOS PROBLEMAS AMBIENTAIS}

Diante do conjunto dos dados para essa segunda parte da pesquisa, primeiramente, realizou-se uma análise dos desenhos produzidos pelos estudantes com base nos elementos/símbolos presentes. Estes foram agrupados em duas categorias: Elementos naturais e Elementos artificiais/construídos. Na categoria dos elementos naturais encontravam-se incluídos os seres bióticos e abióticos e na categoria artificiais/construídos estão os elementos construídos ou transformados pelo ser humano.

A figura 4 ilustra, por ano, em que estavam os estudantes participantes, a ocorrência de elementos das duas categorias, revelando a predominância de símbolos naturalistas em relação aos elementos artificiais/construídos, revelando, assim, 
representações, predominantemente naturalistas de meio ambiente, o que corrobora os resultados encontrados na maioria dos trabalhos de igual tema (TAMAIO, 2002; RODRIGUES e MALAFAIA, 2009; GARRIDO e MEIRELLES, 2011; BUSATO et al, 2012; BASEGGIO, VARGAS e ZANON, 2015).

Figura 4: Ocorrência das categorias dos desenhos dos estudantes revelando a predominância dos símbolos naturalistas

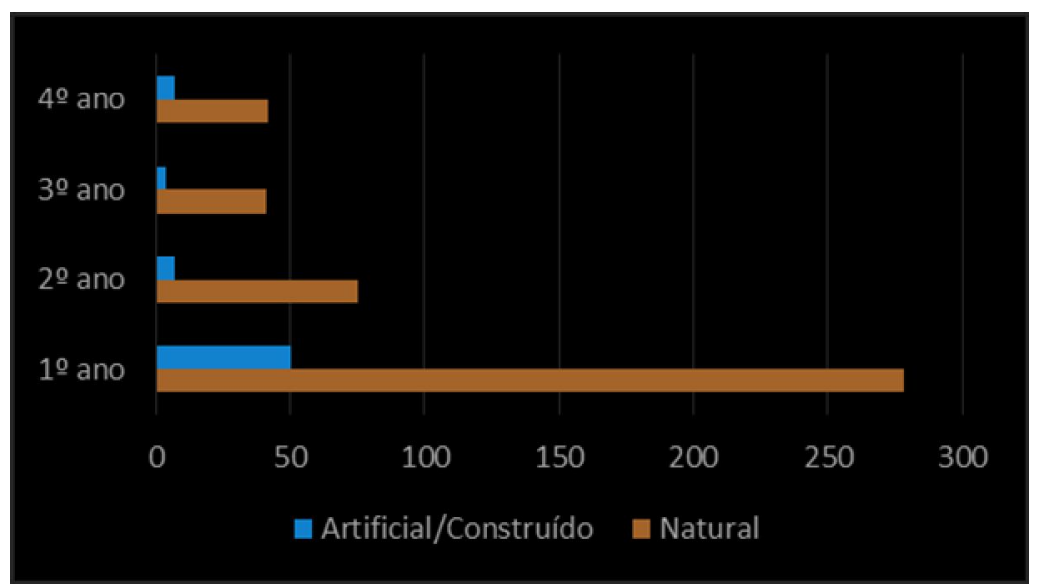

Fonte: elaborado pelas autoras

Na sequência, os discursos coletivos foram construídos, utilizando o conjunto de dados: textos que os estudantes apresentaram após a elaboração dos desenhos, respostas ao questionário e a justificativa para a escolha da imagem representativa de meio ambiente das cinco categorias que foram expostas. Primeiramente, foram identificadas as expressões chaves as quais, em seguida, foram acondicionadas em ideias centrais, o que culminou com a determinação de categorias. A ancoragem para os discursos baseou-se na citação dos estudantes de como ocorrem indícios de educação ambiental em suas trajetórias escolares, não tendo sido realizada uma investigação mais detalhadas sobre outros fatores.

Com relação ao que compreendem por problema ambiental, obtiveram-se duas categorias de discurso. A primeira categoria identifica os problemas ambientais como resultado de causas naturais e a segunda apresenta os efeitos negativos causados pela humanidade ao planeta (Quadro 2). 
Quadro 2: Categorias de discurso sobre o que é um problema ambiental

\begin{tabular}{|c|l|}
\hline \multicolumn{1}{|c|}{ IDEIA } & \multicolumn{1}{|c|}{ DISCURSO COLETIVO } \\
\hline De origem natural & $\begin{array}{l}\text { "Problema ambiental são consequências do desequilíbrio ambiental } \\
\text { ocasionando devastadoras catástrofes, ou seja, é algo que afeta o } \\
\text { equilíbrio do meio ambiente causando impacto negativo ao meio } \\
\text { Ambiente". }\end{array}$ \\
\hline De origem humana & $\begin{array}{l}\text { "Problema ambiental é algo que atinge todo o planeta terra, ou seja, são } \\
\text { ambientes em que tinham grandes quantidades de árvores e animais e } \\
\text { por conta da destruição das florestas, os animais acabam ficando sem } \\
\text { abrigo, alimentos e a caça de animais para fins econômicos acabam } \\
\text { tornando-os extintos por causa do desmatamento, queimadas, poluição } \\
\text { do ar, água, solo, rios, lagos, despejos de esgotos, lixos, aquecimento } \\
\text { global e o desmatamento das matas ciliares. Resumindo é a degradação } \\
\text { da diversidade biológica estendendo a ciclos econômicos estando } \\
\text { relacionando as práticas agropecuárias predadoras ou extrativismo } \\
\text { vegetal é algo que está em desacordo com a preservação do meio } \\
\text { ambiente, e tem a ver com o sistema capitalista". }\end{array}$ \\
\hline
\end{tabular}

\section{Fonte: elaborado pelas autoras}

No primeiro discurso, os estudantes apontam os problemas ambientais como resultado apenas de causas naturais, excluindo as ações antrópicas como parte dos processos de degradação dos recursos naturais e do ambiente. Desse modo, suas representações sobre a origem dos problemas ambientais não levam em consideração o processo histórico-cultural que perfez a sociedade.

O segundo discurso apresenta uma visão mais ampliada sobre as causas/origens dos problemas ambientais, uma vez que assinalam ser a sociedade humana a principal destruidora dos recursos naturais, observando a compreensão de que tais efeitos representam parte de um processo vinculado aos ciclos econômicos, cujo centro é o sistema econômico e político vigente, oferecendo clareza sobre a origem dos problemas enfrentados.

De acordo com Guimarães (2011), nem sempre as origens causadoras dos problemas ambientais são claramente discutidas no processo educativo, havendo, portanto, a necessidade de compreender que não são frutos de uma evolução natural da dinâmica do meio ambiente, mas consequência de uma intervenção antrópica sobre o meio, as quais estão vinculadas ao sistema econômico e político vigente, cuja lógica é transformar tudo em mercadoria e fomentar o seu consumo.

As figuras 5 e 6 apresentam os problemas ambientais com frequências acima de 2 indicados pelos estudantes a partir da solicitação nas escalas: global, nacional e local. As dimensões 'global' e 'nacional' correspondem à escala mais ampla, a local abrange a cidade de Rio Branco, e o bairro refere-se ao domicílio dos estudantes. 
Figura 5: Problemas Ambientais de ampla escala

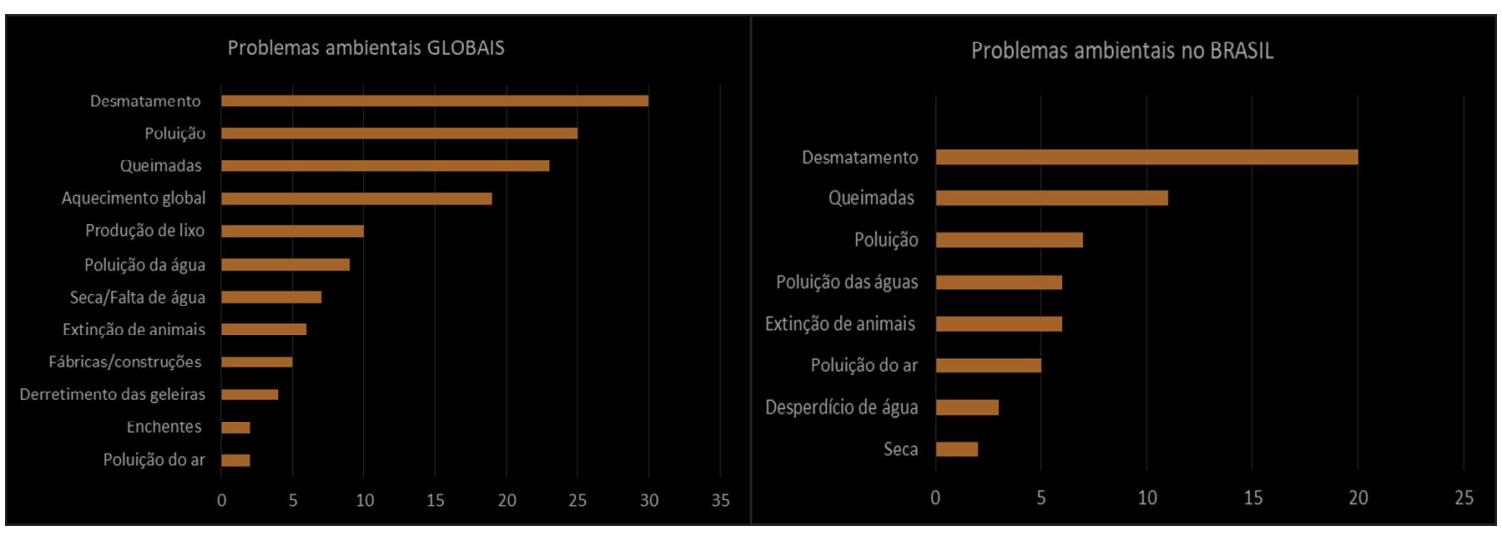

Fonte: elaborado pelas autoras

Tanto na escala global quanto país, ocupam as três primeiras colocações as categorias: desmatamento, queimadas e a poluição de forma geral, seguidos de poluições específicas como da água e do ar (figura 5). O aquecimento global, embora na quarta posição, aparece como um problema de ordem global, o que coincide também com o derretimento das calotas polares, problemas esses possíveis de serem abordados no ensino de ciências e geografia física, assim como amplamente abordados pela mídia.

Figura 6: Problemas Ambientais de escala local

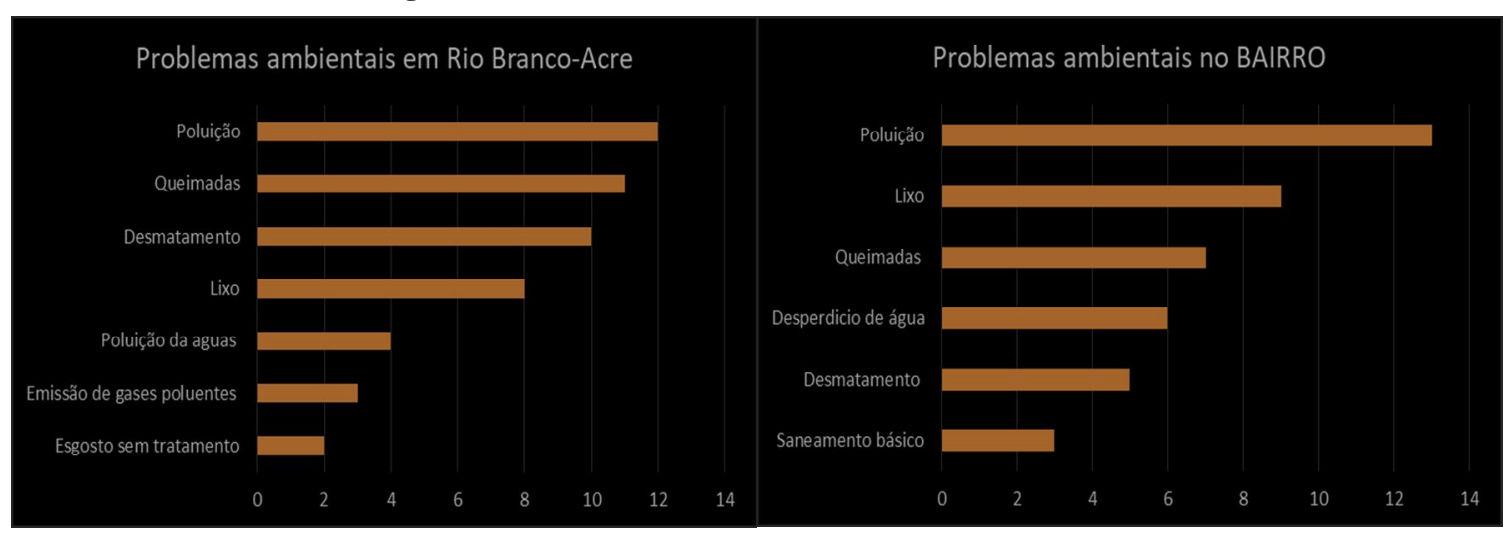

Fonte: elaborado pelas autoras

Com base na figura 6, é possível observar que os problemas ambientais mais mencionados pelos estudantes são semelhantes aos da escala ampla, como, por exemplo o problema da poluição, decorrente do incipiente esgoto e saneamento básico, que são fomentadores da poluição de águas e da aglomeração de resíduos sólidos. O desmatamento e as queimadas se mantêm, mas na dimensão local (bairro) diminui a ocorrência de desmatamento, já que possivelmente foi mencionado em função da expansão imobiliária que está acontecendo nos arredores da cidade de Rio Branco. 
De maneira geral, verifica-se que o desmatamento e as queimadas são problemas inteiramente associados e estes, assim como a poluição, são mencionadas no mesmo grau de proporção nas quatro dimensões, evidenciando, dessa maneira, que os estudantes relacionam os problemas que estão mais próximos de suas realidades, ou seja, aqueles problemas que eles vivenciam diariamente.

No estado do Acre e em toda a Amazônia sul-ocidental, é de conhecimento público que os problemas ambientais estão vinculados ao desmatamento para extração de madeira e expansão da agropecuária, principalmente em atividades voltadas à agropecuária, fato também associado às práticas de queimadas. A poluição envolvendo recursos hídricos e deposição de resíduos está correlacionada com o incipiente saneamento básico, gestão dos resíduos sólidos e despejo de esgotamento sanitário in natura diretamente em igarapés e rios.

Ao serem indagados se há relação entre os problemas ambientais citados e a saúde humana, foi possível encontrar cinco categorias de discursos relacionadas a problemas específicos (Quadro 3).

Quadro 3: Relação entre os problemas ambientais e a saúde humana

\begin{tabular}{|l|l|}
\hline IDEIA CENTRAL & \multicolumn{1}{c|}{ DISCURSO COLETIVO } \\
\hline $\begin{array}{l}\text { Fumaça (doenças } \\
\text { respiratórias) }\end{array}$ & $\begin{array}{l}\text { "Há relação entre os problemas ambientais e a saúde humana, pois os } \\
\text { problemas ambientais contribuem para que as doenças apareçam ou se } \\
\text { agravem como, por exemplo, em épocas de queimadas os problemas } \\
\text { aumentam, pois as fumaças provenientes das queimadas causam } \\
\text { problemas respiratórios. Além disso, a fumaça tóxica pode causar } \\
\text { câncer de pulmão e a emissão de CO2 e outros gases fazem com que a } \\
\text { temperatura se eleve causando desidratação nas pessoas e as crianças } \\
\text { são as que mais sofrem. Resumindo, os problemas ambientais só } \\
\text { trazem piora para a saúde humana". }\end{array}$ \\
\hline $\begin{array}{l}\text { Contaminação das } \\
\text { águas por dejetos } \\
\text { (doenças } \\
\text { veiculação hídrica) }\end{array}$ & $\begin{array}{l}\text { "Sim, pois existe um grande problema como a contaminação da água, } \\
\text { ou seja, a péssima qualidade da água do Rio Acre que é utilizada para } \\
\text { o consumo e não tem o devido tratamento pode causar doenças aos } \\
\text { seres humanos como hepatite e Amebíase. E as enchentes também } \\
\text { podem causar doenças nos seres humanos como leptospirose e } \\
\text { Esquistossomose". }\end{array}$ \\
\hline $\begin{array}{l}\text { Contaminação do } \\
\text { solo e da água por } \\
\text { agrotóxicos } \\
\text { fertilizante (doenças } \\
\text { degenerativas) }\end{array}$ & $\begin{array}{l}\text { "Plantação com adubos químicos, que agride tanto o meio ambiente } \\
\text { como a nós mesmos, ou seja, com os agrotóxicos nas lavouras que vai } \\
\text { para o solo e lençóis freáticos contaminando a água e causando } \\
\text { grandes problemas ao ambiente e a saúde das pessoas como os } \\
\text { diversos tipos de câncer.". }\end{array}$ \\
\hline $\begin{array}{l}\text { Incipiente } \\
\text { Saneamento Básico } \\
\text { (doenças } \\
\text { epidemiológicas) }\end{array}$ & $\begin{array}{l}\text { "A falta de saneamento básico afeta a saúde humana e os esgotos a céu } \\
\text { aberto atraem muitos ratos e também insetos como baratas, e estes } \\
\text { podem causar grandes transtornos à população. Resumindo através dos } \\
\text { problemas ambientais surgem diversas doenças hoje não só o Brasil } \\
\text { como o mundo inteiro sofre com a epidemia da Dengue que hoje } \\
\text { transmite uma nova doença, a zika vírus, o mosquito pode ser } \\
\text { encontrado em qualquer lugar onde exista água parada e o lixo que } \\
\text { jogamos nos quintais ou até mesmo na rua que pode contribuir para }\end{array}$ \\
\hline
\end{tabular}




\begin{tabular}{|l|l|}
\hline & $\begin{array}{l}\text { sua reprodução, assim aumentando o índice de doenças um caso } \\
\text { recente que estamos vivendo e a epidemia do zika, cujo maior } \\
\text { responsável somos nós, que acumulamos água nos quintais e não } \\
\text { praticamos uma educação ambiental". }\end{array}$ \\
\hline
\end{tabular}

Fonte: elaborado pelas autoras

A primeira categoria refere-se aos efeitos do desmatamento e das queimadas que emitem fumaça e chegam a cobrir os centros urbanos, atingindo um número significativo de pessoas, principalmente idosos e crianças, faixas etárias mais vulneráveis a esses tipos de problemas durante a estação do verão. A poluição dos recursos hídricos está associada ao despejo de esgotos in natura e às situações de enchentes. Esta última, embora não tenha sido mencionada como um problema ambiental na escala local, mostra uma questão que atinge, anualmente, a população que reside em locais de ocupação irregular como margens e várzeas de rios e igarapés, situação que além de apresentar prejuízos materiais, leva à contaminação das águas em virtude do contato direto com as áreas construídas.

O uso de agrotóxicos e fertilizantes sintéticos na agropecuária foi mencionado como potente contaminador do solo e, também, dos recursos hídricos, pois afetam a saúde humana e está associado a doenças degenerativas. Outro problema ambiental de impacto direto à saúde mencionado, relaciona-se ao incipiente saneamento ambiental, a exemplo, de águas servidas serem esgotadas a céu aberto, o que colabora para a proliferação de mosquitos e doenças associadas como a dengue e a zika o que atualmente tem deixado as instituições de saúde em alerta devido à ampliação do número de casos (SANTOS et al, 2015). A disposição inadequada de lixo ocasiona também a proliferação de animais e insetos, muitos destes vetores de zoonoses, transmissores de doenças.

Foi possível observar que os estudantes pesquisados correlacionam alguns dos problemas ambientais citados com a saúde ambiental e humana. No entanto, não fica claro se compreendem que tais problemas estão associados com outras questões de natureza política, econômica, social e cultural. De acordo com Brügger (2004), as questões ambientais, tomando por base o modelo "adestrador", normalmente, são tratadas sob as dimensões naturais e técnicas e não mediante uma abordagem socioambiental, a qual está na base da educação ambiental crítica. Conforme a autora, isso é resultado da fragmentação do conhecimento "que estabeleceu um diálogo extremamente pobre entre as Ciências Humanas e as Ciências Naturais e Exatas”. 
Quanto às representações sobre o meio ambiente, foram obtidos sete diferentes discursos coletivos que foram agrupados em duas macrocategorias: Representações Limitadas e Integradas de Meio Ambiente.

A macrocategoria de Representação Limitada foi composta pelas categorias: Meio Ambiente Harmônico/idealizado, Meio Ambiente Reducionista, Meio Ambiente Utilitarista, Meio Ambiente com foco nos problemas e Meio Ambiente com foco na preservação. Tais categorias foram consideradas de representação limitada porque representam o meio ambiente apreendido como natureza para apreciar, respeitar, preservar, não ser tocado, como meramente provedor de recursos para vida humana, ou como um problema causado por outros, não havendo a percepção de pertencimento sobre ele. Quando o ser humano foi representado em alguns desenhos, foi apenas como "mero contemplador das belezas naturais".

As representações de meio ambiente de visão limitada (quadro 4) vinculam-se a educação ambiental classificada por Brügger (2004) como "adestramento ambiental". Trata-se de um modelo conservacionista de se pensar e praticar a educação ambiental em que os aspectos ecológicos e conservacionistas na ação educativa, reduzindo-se ao contexto natural e técnico, são priorizados. Assim, a educação ambiental puramente praticada sob essa perspectiva, tem sido conduzida e nivelada por discursos e práticas que se balizam pelo uso racional dos recursos naturais, obedecendo ao nível ideal de produtividade dos ecossistemas naturais ou gerenciados pelos seres humanos.

Reigota (2007) afirma que, nesse contexto, a prática pedagógica baseada na transmissão de conhecimentos sobre a natureza gera representações de meio ambiente naturalistas, em que o homem é concebido como mero expectador. O autor considera ainda que a educação ambiental nessa perspectiva possa levar à construção de representações de meio ambiente antropocêntricas, que nesse estudo foi categorizada como utilitarista.

Quanto à macrocategoria meio ambiente de visão integrada (quadro 5), as ideias centrais dos discursos culminaram em duas categorias: meio ambiente abrangente e meio ambiente socioambiental. Ao contrário da primeira, as representações estão fortemente vinculadas à inserção do ser humano como elemento constituinte do meio ambiente, sendo, inclusive, os problemas ambientais apontados como resultado do processo histórico de apropriação do ser humano à natureza por meio de seus modelos socioeconômicos. Essas duas categorias aproximam-se das representações de meio ambiente que estão alicerçadas em uma educação ambiental crítica, em que o elemento 
central é o da compreensão da crise ambiental e seus desdobramentos, a partir do modelo vigente que orienta a sociedade e sua relação com e no meio ambiente. Segundo Lima (2009), a educação ambiental, nessa perspectiva, tende a rejeitar o antropocentrismo e a consequente subordinação à natureza, requerendo ainda respostas transformadoras tanto políticas como éticas.

$\mathrm{O}$ quadro 4 apresenta os discursos vinculados à macrocategoria de discursos limitados de meio ambiente.

Quadro 4: Discursos de Meio Ambiente Limitado

\begin{tabular}{|c|c|}
\hline CATEGORIAS & DISCURSO COLETIVO \\
\hline NATURALISTA & $\begin{array}{l}\text { "O que vem na minha cabeça quando penso na palavra meio ambiente } \\
\text { é natureza, os seres vivos e o espaço onde encontramos fatores bióticos } \\
\text { e abióticos, os animais, vegetais a terra e água, em fim habitats } \\
\text { naturais, ou seja, um lugar mais preservado com bastantes árvores. É o } \\
\text { local onde vive a maior diversidade. É um conjunto de unidades } \\
\text { ecológicas que funcionam como um sistema natural, toda vegetação, } \\
\text { animais microrganismos, solo, rochas. Resumindo, um lugar recheado } \\
\text { de uma natureza não habitada pelo homem, onde não tem o dedo do ser } \\
\text { humano para mudá-la. Enfim, é tudo de natural que Deus criou" }\end{array}$ \\
\hline $\begin{array}{l}\text { HARMÔNICO- } \\
\text { DESEJADO }\end{array}$ & $\begin{array}{l}\text { "Meio ambiente é onde todos os seres vivem em harmonia e estão } \\
\text { protegidos, muita água, luz solar e plantas é um lugar tranquilo, calmo, } \\
\text { com natureza pura e cheia de vida, ou seja, um local onde vivemos ...é } \\
\text { uma alternância entre as contribuições do homem e a natureza sem que } \\
\text { haja conflito entre elas vivendo de forma harmônica. O homem está } \\
\text { inserido na natureza sem degradar e sem derrubar. Resumindo Meio } \\
\text { ambiente é assim com bastante vida, com bastante cor viva um lugar } \\
\text { lindo de descanso onde existem pessoas e animais em harmonia com a } \\
\text { natureza em uma relação sem agressões. Há contato saudável do } \\
\text { homem sem nenhum tipo de desmatamento. Não vemos a ação dele, } \\
\text { isso é muito importante para podermos viver bem e ter bastante saúde". }\end{array}$ \\
\hline $\begin{array}{c}\text { COM FOCO NOS } \\
\text { PROBLEMAS }\end{array}$ & $\begin{array}{l}\text { "Somos fruto do meio ambiente, mas não estamos valorizando nosso } \\
\text { planeta. O meio ambiente já foi muito bonito, continua sendo, porém } \\
\text { com marcas de queimadas. É triste ver grandes hectares sendo } \\
\text { desmatadas e queimadas para diversos fins. A água já é um problema } \\
\text { mundial o consumismo, os novos automóveis poluem mais do que } \\
\text { você imagina. Nosso planeta pede socorro, grita aos quatro ventos que } \\
\text { parem de desmatarem nossas matas, parem de jogar lixo em nossos } \\
\text { rios, que tudo, floresta é bem mais refrescante que uma cidade. Meio } \\
\text { ambiente é algo fundamental para a vida pode se esgotar por ações de } \\
\text { irresponsabilidade de exploração de recursos e que devemos nos } \\
\text { atentar para isso. O planeta terra precisa urgentemente de ajuda, e } \\
\text { quem pode dar essa ajuda é quem está destruindo. Ainda podemos } \\
\text { salvar o planeta. Com a consciência de todos nós podemos salvá-lo". }\end{array}$ \\
\hline UTILITARISTA & $\begin{array}{l}\text { "Meio ambiente na minha concepção é o estado em que o nosso } \\
\text { planeta se encontra sobre o que ele pode nos oferecer e nós a ele, ou } \\
\text { seja, Meio ambiente é a existência de muitos animais, entre esses } \\
\text { animais tem o coelho que pode ser comercializado, deveríamos cuidar } \\
\text { da nossa natureza, pois ela é que nos dar os mantimentos. A floresta é } \\
\text { especial graças a ela que respiramos esse ar fresco seria um problema } \\
\text { se o meio ambiente sumisse já que utilizamos florestas, ervas } \\
\text { medicinais que nós encontramos na natureza. Resumindo meio }\end{array}$ \\
\hline
\end{tabular}




\begin{tabular}{|l|l|}
\hline & $\begin{array}{l}\text { ambiente é um lugar que deve ser preservado para a sustentabilidade } \\
\text { do ser humano, desde que seja feita de forma adequada, devemos } \\
\text { preservar, pois, dependemos dele para nossa sobrevivência como: As } \\
\text { florestas, os rios, ar, sol, todos em geral devemos preservá-lo, pois } \\
\text { dependemos dele para nossa sobrevivência e também para que as } \\
\text { futuras gerações tenham um bom desenvolvimento em todos os } \\
\text { aspectos de vida. A natureza é tudo o que ela nos proporciona". }\end{array}$ \\
\hline $\begin{array}{l}\text { FOCO NRESERVAÇÃO } \\
\text { "Meio ambiente é o espaço onde vivemos e cuidamos para preservá-lo, } \\
\text { não jogar lixo nas ruas, não fazer queimadas, não derrubar as árvores, } \\
\text { pois estamos todos no mesmo meio, sem agredir a natureza, ou seja, } \\
\text { um ambiente limpo sem a poluição do homem nem a caça e os animais } \\
\text { estão livres no habitat. Resumindo meio ambiente é interação entre } \\
\text { seres vivos, conservação da floresta da fauna..." }\end{array}$ \\
\hline
\end{tabular}

\section{Fonte: elaborado pelas autoras}

O primeiro discurso remete-se ao meio ambiente reducionista, em que os estudantes o representam apenas a partir da dimensão natural, destacando-se os elementos bióticos e abióticos. O discurso ancora-se na ideia de que o meio ambiente é "uma forma bruta com ausência do ser humano", ficando claro o distanciamento entre o ser humano e a natureza. Quando destacam que o meio ambiente é "tudo que Deus criou", referem-se ao que não foi modificado, afastando qualquer ação ou criação humana.

A segunda categoria de meio ambiente de maior expressividade foi a harmônica/idealizada. As expressões chaves que compuseram essa categoria se aproximam bastante da categoria romântica de natureza descrita por Tamaio (2000), principalmente, em virtude de o meio ambiente, nesta representação, ser sinônimo de natureza, apregoando-se o enaltecimento dela. Observa-se, portanto, que os estudantes apontam a grandiosidade do meio ambiente dando importante ênfase a sua beleza estética. Contudo, há um diferencial, que é a inserção do homem, porém mediante uma relação passiva e de comunhão, principalmente, no que se refere ao usufruto das paisagens naturais. No entanto, não é possível notar, nos discursos, expressões que vislumbrem sobre a integração do homem ao meio ambiente, uma vez que não é mencionado nenhum trecho que remeta aos aspectos sociais e culturais que o homem estabeleceu historicamente enquanto elemento integrante desse universo.

$\mathrm{O}$ meio ambiente com foco nos problemas assemelha-se à categoria socioambiental descrita por Tamaio (2002), na qual o ser humano é apontado como o "grande vilão" e causador da degradação ambiental. Todavia, consideramos o discurso mais aproximado de uma representação limitada, uma vez que os sujeitos não compreendem que as mudanças e os processos degradantes que ocorrem ao meio ambiente são resultantes não do ser humano como sujeito "mau", mas como reflexo do 
modelo de desenvolvimento que a sociedade foi consolidando ao longo dos tempos. Desse modo, o discurso é reduzido a atitudes de "denúncia e apelo", apontando soluções baseadas em processo de conscientização, não sendo possível observar nenhuma reflexão crítica de como os problemas ambientais podem ser solucionados na prática. Tal representação pode ser considerada resultante das atividades de educação ambiental que remetem aos problemas ambientais e a soluções vinculadas a processos de conscientização. Como bem orienta Sauvé (2005a), nesse caso, há uma necessidade de esclarecer que os problemas ambientais estão "essencialmente associados às questões socioambientais ligadas a jogos de interesses e de poder, e a escolha de valores".

No que se refere à categoria de meio ambiente com foco na preservação, embora em um trecho do discurso apareça a expressão “ ... meio ambiente é interação entre seres vivos" e a figura humana está presente “...é o espaço onde vivemos”, a ideia central que compõe o discurso vincula-se a atitudes de preservação/conservação do ambiente relacionadas a condicionamento de resíduos sólidos, proteção aos animais e a conservação da floresta perante às práticas de desmatamento e queimadas, problemas esses que evidenciam de forma expressiva o contexto local.

A forma como esses sujeitos demostram compreenderem o meio ambiente nos leva a inferir que a educação ambiental por estes recebida apresenta forte tendência preservacionista/conservacionista como resolução dos problemas ambientais. Essa representação está estreitamente vinculada às ações de mutirão de limpeza dos arredores da escola e das áreas verdes visitadas (parques e hortos).

Obteve-se também um discurso vinculado ao meio ambiente utilitarista, que possui base na representação antropocêntrica identificada por Reigota (2007), na qual as ideias estão centradas do usufruto dos bens naturais pela humanidade. Assim, as preocupações pela conservação e preservação dos recursos naturais têm como justificativa os benefícios diretos à humanidade, muito bem ilustrado pela frase comumente proferida "preservar para garantir as futuras gerações".

Apesar de ter ocorrido uma predominância de discursos que revelaram uma compreensão limitada de meio ambiente (considerando a educação ambiental crítica como parâmetro), foi possível identificar duas categorias de discursos que revelam entendimentos mais integrados da relação do ser humano com a natureza.

Nesta segunda macrocategoria, denominada de representações de visão integrada, foram identificadas as categorias abrangente e socioambiental, as quais foram descritas por Tamaio (2002) e, também, por Rodrigues e Malafaia (2009). Nesse grupo, 
foram alocados discursos que reconhecem o ser humano como parte do meio ambiente, por meio de sua relação neste, mesmo que essas relações resultem em circunstâncias negativas como a degradação ambiental (Quadro 5).

\section{Quadro 5: Discursos de Meio Ambiente Integrado}

\begin{tabular}{|c|l|}
\hline CATEGORIAS & \multicolumn{1}{|c|}{ DISCURSO COLETIVO } \\
\hline ABRANGENTE & $\begin{array}{l}\text { "Quando penso em meio ambiente vem a minha cabeça tudo o que } \\
\text { existe no planeta. É o ambiente em que vivemos seja nossa casa, no } \\
\text { trabalho, na escola ou na rua é tudo o que está ao nosso redor, } \\
\text { mesmo nas coisas tão pequenas como nas maiores, é tudo que meus } \\
\text { olhos podem contemplar, vai da natureza a construções" }\end{array}$ \\
\hline SOCIOAMBIENTAL & $\begin{array}{l}\text { "O que vem na minha cabeça quando penso em meio ambiente é o } \\
\text { meio em que vivemos e tudo que faz parte dele, este meio pode ser } \\
\text { o urbano ou o rural, a floresta, os rios, os lixos, o desmatamento, a } \\
\text { poluição, animais, a própria cidade e nós seres racionais. } \\
\text { Resumindo meio ambiente está relacionada ao conjunto do } \\
\text { universo, onde está envolvida o mundo todo, desde a floresta, } \\
\text { cidade, animais, vegetação, clima, rios, mares, atmosfera, } \\
\text { ecossistemas, cadeia alimentar e a interação do homem com a } \\
\text { natureza e suas construções, ou seja, o ambiente como é de verdade, } \\
\text { às vezes desmatando para construir cidades, criação e plantio a } \\
\text { degradação, exploração do meio ambiente. Assim nossas florestas, } \\
\text { árvores começam a desaparecer dando lugar a floresta de concreto. } \\
\text { Estamos com os dias contados devido a devastação e intervenção do } \\
\text { homem capitalista.... quando um lugar tem riqueza o homem } \\
\text { explora seus recursos até o fim, depois as regiões ficam desertas e } \\
\text { sem plantações. O ar vai ficando menor, o mundo vai se } \\
\text { autodestruindo" }\end{array}$ \\
\hline
\end{tabular}

\section{Fonte: elaborado pelas autoras}

O discurso de meio ambiente na perspectiva abrangente, revela uma visão ampla, abstrata e complexa de representar o meio ambiente (FONTANA, 2002). Conforme Venturieri e Santana (2016) observam-se, nessas representações, a abrangência não somente dos aspectos naturais, "mas, também, os resultantes das atividades humanas, ocasionando a interação de fatores biológicos, físicos e econômicos". O trecho "...é tudo que meus olhos podem contemplar, vai da natureza a construções" remete a uma totalidade que inclui tanto os aspectos naturais como também aqueles resultantes da intervenção humana, embora ainda não seja perceptível que esse grupo de sujeitos consigam relacionar as transformações humanas a um processo histórico-cultural mediado socialmente.

Por fim, apresenta-se o discurso do qual consideramos o que mais se aproxima da tendência educação ambiental crítica ("socioambiental"), ou seja, aquela que nas palavras de Loureiro (2004) requer o pensamento complexo sobre as verdadeiras causas da crise civilizatória as quais integram questões sociais, políticas, econômicas, culturais e ambientais. 
Assim, é passível de reconhecimento que os estudantes que apresentaram discurso que convergem para a categoria socioambiental, compreendem o meio ambiente dentro de uma abordagem histórico-cultural. Assim, ser humano e paisagem constituem unidades da natureza, paisagens estas que vão se transformando pela intensa atividade humana a qual atende a lógica do sistema capitalista. Expressões contidas neste discurso promovem a percepção de que os sujeitos consideram os processos degradantes resultantes da forma como o ser humano historicamente apropriou-se dos recursos naturais mediados pelas formas de acumulação, resultando no sistema capitalista como impulsionador da exploração. Nesse sentido, trata-se, sem restrição, de uma representação de meio ambiente em seu caráter complexo, no qual são reconhecidos fatores fundamentais para compreender as mazelas com as quais a vida moderna se depara, fatores que associam questões ambientais, sociais, políticas, econômicas e culturais mencionadas anteriormente.

\section{CONSIDERAÇÕES FINAIS}

Diante dos resultados alcançados, observou-se que as representações dos sujeitos investigados quanto ao meio ambiente e os problemas ambientais assemelham-se com as tendências de educação ambiental escolar pelas quais perpassaram, aqui explicitadas por meio das atividades registradas pelos estudantes, que podem ter sido influenciadas por ideias reproduzidas pelos meios de comunicação em geral.

As atividades permeadas por ações de conscientização dos estudantes quanto à preservação dos recursos em função de sua utilização e dos quais dependem para sua sobrevivência, sem relacionar a lógica do mercado/consumo revelam a educação ambiental, em um modelo de "adestramento ambiental". Nesses termos, as atividades mencionadas pelos estudantes como referentes à educação ambiental na escola, a exemplo das visitas a parques ambientais, reciclagem de material descartável, retirada de lixo do quintal da escola e comemoração às datas alusivas ao meio ambiente, não são capazes de dar conta da verdadeira complexidade ambiental, levando a concepções e posicionamentos limitados sobre a questão.

A partir dos discursos coletivos, fica perceptível uma predominância de representações de meio ambiente desvinculadas da sua complexidade, ou seja, que não apresentam o verdadeiro entendimento da sua magnitude e das discussões sobre os 
processos que o alteram significativamente e impactam diretamente sobre os recursos naturais, as diversas formas de vida, incluindo as condições sociais e de saúde humana.

Os discursos que vislumbram representações limitadas de meio ambiente precisam ser revistos no sentido de ampliá-los e não de eliminá-los. Nota-se, com isso, a importância de se identificar as representações sobre o tema, previamente, às intenções de promover a educação ambiental. Ressaltamos ainda o reconhecimento dos aspectos da vida social dos estudantes e seu meio familiar a fim de promover a educação ambiental crítico-transformadora. Conforme Reigota (2009), a educação ambiental é um instrumento de transformação dos indivíduos na sociedade, não estando limitada apenas à preservação dos recursos naturais e espécies, mas abrangendo as relações sociais, políticas, econômicas, sociais e culturais que são estabelecidas entre a humanidade e a natureza.

Levando em consideração o estudo realizado por Freitas, Panzeri e Meirelles (2015) que buscaram identificar o marco da educação ambiental no IFAC, observando a fragilidade desse campo político da educação na educação básica (TOZONI-REIS, CAMPOS, 2015), faz-se necessário que a instituição, além de criar a sua política de educação ambiental, também invista em espaços de formação continuada de seu corpo docente com o objetivo de melhor prepará-los para ampliações das representações de meio ambiente dos estudantes. É crucial que esta seja problematizadora, contextualizada e interdisciplinar como bem destaca Torres (2010); Torres, Ferrari e Maestrelli (2014) ao fazerem uma leitura dos documentos regulamentares da educação ambiental em território nacional.

Com relação à metodologia, o método do discurso do sujeito coletivo, demostrou eficiência no resgate das representações, revelando como os estudantes percebem e se relacionam com o meio ambiente e os problemas ambientais no cotidiano. Entretanto, vale destacar que a metodologia limita-se em virtude de nem sempre haver o estabelecimento da ancoragem dos discursos.

Ressaltamos que os resultados aqui encontrados quanto às representações sociais sobre o meio ambiente e os problemas ambientais foram adotadas como elemento norteador na inserção da temática ambiental via abordagem temática Freiriana na perspectiva da educação crítico-transformadora (FREITAS, MEIRELLES, 2017). Acreditamos que processos de educação ambiental pelo viés crítico-transformador são capazes de levarem sujeitos sociais a construírem conhecimentos, atitudes, comportamentos e valores dos quais possam se posicionar criticamente em meio à 
lógica capitalista, a qual tem sido apontada como cerne da crise enfrentada pelo mundo contemporâneo, podendo, ainda, os sujeitos intervirem, efetivamente, em suas realidades socioambientais.

\section{REFERÊNCIAS BIBLIOGRÁFICAS}

AIELLO-VAISBERG, T. M. J. Investigações de representações sociais. In: TRINCA, W. (org): Formas de investigação clínica em psicologia: procedimentos de desenhoestórias. São Paulo: Vetor, 1997. p. 255 -288.

ALEXANDRE, M. Representação Social: uma genealogia do conceito. Revista Comum, Rio de Janeiro, RJ. v. 10, n. 23, p. 122-138, 2004. Disponível em: http://www.sinpro-rio.org.br/imagens/espaco-do-professor/sala-de-aula/marcosalexandre/Artigo7.pdf. Acessado em: 11 de fevereiro de 2017.

ARRUDA, A. Teoria das representações sociais e teorias de gênero. Caderno de Pesquisa, n. 117, p. 127-149, 2002. Disponível em: http://www.scielo.br/pdf/cp/n117/15555.pdf. Acessado em: 03 de agosto de 2017.

BASEGGIO, K.R.; VARGAS, I.A; ZANON, A.M. Uso de mapas mentais em sala de aula: uma análise de representações sobre o meio ambiente. In: Encontro Pesquisa em Educação Ambiental, 8., Anais..., Rio de Janeiro, 2015. Disponível em: http://epea.tmp.br/epea2015_anais/pdfs/plenary/71.pdf . Acessado em: 18 de junho de 2017.

BIZERRIL, M. X. A.; FARIA D. S. Percepção de professores sobre a Educação Ambiental no Ensino Fundamental. Revista Brasileira Estudos Pedagógicos, Brasília, v. 82, n. 200/201/202, p. 57-69, 2001. Disponível em: http://rbep.inep.gov.br/index.php/rbep/article/view/917. Acessado em: 03 de agosto de 2017.

BRÜGGER, P. Educação ou adestramento ambiental?. Florianópolis: Letras Contemporâneas, 2004.

BUSATO, C; BUSATO, J; VENTURIN, A.; BUSATO, C.C. M. Representações sociais de Meio Ambiente em estudantes de ensino médio/técnico dos estados do Espirito

Santos e Paraná. Revista Engenharia Ambiental. V. 9, n. 3, p 352-369, jul/set., 2002. Disponível em:

http://ferramentas.unipinhal.edu.br/engenhariaambiental/include/getdoc.php?id=2314\& article=774\&mode=pdf. Acessado em: 12 de junho de 2017 .

CAMARGO, L. J. Representações Sociais acerca do Meio Ambiente de Moradores do Entorno de uma Unidade de Conservação em Campinas-SP. In: Encontro Nacional da Anppas, 6., Anais..., Brasília, 2008. Disponível em: http://www.anppas.org.br/encontro4/cd/ARQUIVOS/GT9-508-33620080509233318.pdf. Acessado em: 20 de abril de 2017.

CARDOSO, F. A.; FRENEDOSO, R. C.; ARAÚJO, M. S. T. Concepções de Meio Ambiente entre estudantes de licenciatura em ciências biológicas. Revista brasileira de Educação Ambiental, São Paulo, V.10, No 2: 95-112, 2015. Disponível em: http://www.sbecotur.org.br/revbea/index.php/revbea/article/viewFile/4380/3006. Acessado em: 28 de abril de 2017. 
CARVALHO, I. C. M. Transformações na esfera pública e ecologia: educação e política em tempos de crise da modernidade. In: COSTA, C. A. S.; e LOUREIRO, C. F. B. (Orgs.). A questão ambiental: interfaces críticas. $1^{\text {a }}$ ed. Curitiba: Appris Editora e Livraria Ltda-ME, 2013, v. 1, p. 109-122.

CATALÃO, V. L. Desenvolvimento sustentável e Educação Ambiental no Brasil. In: PÁDUA, J.A. Desenvolvimento, justiça e meio ambiente (Org.): Belo Horizonte: Editora UFMG, 2009.

DUARTE, S. J. H; MAMEDE, M.V; ANDRADE, S. M. O. Opções TeóricoMetodológicas em pesquisas qualitativas: Representações Sociais e Discurso do Sujeito Coletivo. Revista Saúde e Sociedade. São Paulo, v. 18, n.4, p. 620, 2009. Disponível em: http://www.scielo.br/pdf/sausoc/v18n4/06.pdf. Acessado em: 20 de junho 2017.

FREITAS, R.A.; PANZERI, C.G.; MEIRELLES, R. M S. Marco Inicial da Educação Ambiental no Instituto Federal de Educação, Ciência e Tecnologia do Acre (IFAC). In: Encontro Nacional de Pesquisa em Educação em Ciências, 10., Anais...Águas de Lindóia, 2015. Disponível em: http://www.abrapecnet.org.br/enpec/xenpec/anais2015/resumos/R0795-1.PDF. Acessado em: 24 de março de 2017.

FREITAS, R.G.A; MEIRELLES, R.M.S. Abordagem socioambiental na educação profissionalizante: uma experiência via investigação temática. Revista Pesquisa em Educação Ambiental, São Paulo, v. 12, n.2, dez/2017.

GARRIDO, L.S., MEIRELLES, R. M.S. Percepção sobre meio ambiente por alunos das séries iniciais do Ensino Fundamental: considerações à luz de Marx e de Paulo Freire.

Revista Ciência \& Educação, Bauru, v. 20, n. 3, p. 671-685, 2014. Disponível em: http://www.scielo.br/scielo.php?pid=S1516-

$73132014000300671 \&$ script=sci_abstract\&tlng=pt . Acessado em: 03 de agosto de 2017.

GUIMARÃES, M. Armadilha paradigmática na educação ambiental. In LOUREIRO, C.F.B.; LAYRARGUES, P.P.; CASTRO, R.S.de (orgs.). Pensamento complexo, dialética e educação ambiental. $2^{a}$ ed. São Paulo: Cortez, 2011.

JODELET, D. Representações sociais: um domínio em expansão. In: JODELET, D. (org.): As Representações sociais. Rio de Janeiro: Eduerj, 2002, p.17-44.

LAYRARGUES, P. P.; LIMA, G. F. C. Mapeando as macro-tendências políticopedagógicas da Educação Ambiental contemporânea no Brasil. In: Encontro Pesquisa em Educação Ambiental, 6., Anais .... Ribeirão Preto, 2011. Disponível em: http://www.icmbio.gov.br/educacaoambiental/images/stories/biblioteca/educacao_ambi ental/Layrargues_e_Lima_-_Mapeando_as_macrotend\%C3\%83\%C2\%AAncias_da_EA.pdf . Acessado em: 26 de fevereiro de 2018.

LAYRARGUES, P. P.; LIMA, G. F. C. As macrotendências político-pedagógicas da educação ambiental brasileira. In: Revista Ambiente \& Sociedade, São Paulo, v. XVII, n. 1, p. 23-40, jan./mar. 2014. Disponível em:

http://www.scielo.br/scielo.php?script=sci_arttext\&pid=S1414-753X2014000100003.

Acessado em: 29 de maio de 2017.

LEFÉVRE, F.; LEFÉVRE, A. M. C. O discurso do sujeito coletivo: um novo enfoque em pesquisa qualitativa (desdobramentos). 2. Ed. Caxias do Sul: Educs, 2005.

LEFF, E. Saber Ambiental: Sustentabilidade, Racionalidade, Complexidade, Poder. Petrópolis: Vozes, 2004. 
LIMA, G. F. C. Educação ambiental crítica: do socioambientalismo às sociedades sustentáveis. Revista Educação e Pesquisa, São Paulo, v.35, n.1, p. 145-163, jan./abr. 2009. Disponível em: http://www.scielo.br/pdf/ep/v35n1/a10v35n1.pdf. Acessado em: 26 fevereiro de 2018

LEROY, J.P.; PACHECO, T. Dilemas de uma educação em tempo de crise. In: LOUREIRO, C. F. B.; LAYRARGUES, P. P.; CASTRO, R. S. (Orgs.): Pensamento complexo, dialética e educação ambiental. $2^{\circ}$ ed. São Paulo: Cortez, 2011, p. $30-71$.

LOUREIRO, C. F. B. Trajetórias e Fundamentos da Educação Ambiental. São Paulo. Cortez. 2004.

MEDEIROS, D. Tabagismo e futuros profissionais de saúde: análise das representações sociais no Brasil e na Espanha. Tese de doutorado. Universidade de São Paulo (USP). Faculdade de Saúde Pública. São Paulo: 2014. Disponível em: http://www.teses.usp.br/teses/disponiveis/6/6135/tde-05032015-125106/pt-br.php. Acessado em: 07 de agosto de 2017.

MINAYO, M. C. S. O conceito de representações sociais dentro da sociologia clássica. In: GUARESCHI, P.; JOVCHELOVITCH, S. (org). Textos em representações sociais. 10. Ed. Petrópolis: Vozes, 2008, p. 89-111.

MOSCOVICI, S. Representações sociais: investigações em psicologia social. Petrópolis, RJ: [s.n.] 2003.

REIGOTA, M. A.S. Meio ambiente e representação social. 7. ed. São Paulo: Cortez, 2007.

REIGOTA, M. A. S. O que é Educação Ambiental. 2. ed. São Paulo: Brasiliense, 2009.

RODRIGUES, A. S. L; MALAFAIA, G. O meio ambiente na concepção de discentes no município de Ouro Preto-MG. REA - Revista de estudos ambientais (Online) v.11, n. 2, p. 44-58, jul./dez. 2009. Disponível em:

http://gorila.furb.br/ojs/index.php/rea/article/viewFile/1514/1199. Acessado em: 26 de fevereiro de 2018.

SÁ, C. P. A construção do objeto de pesquisa em representações de pesquisa. Rio de Janeiro: EdUERJ, 1998. 110 p.

SANTOS, D. N. S.; AQUINO, E. M. L; MENEZES, G. M. S.; PAIM, J. S; SILVA, L. M. V.; PORTELA, F. S; TEIXEIRA, M. G; BARRETOS, M.L. Documento de posição sobre a tríplice epidemia de Zika-Dengue-Chikungunya. Observatório de análise política em saúde. Instituto de Saúde Coletiva - Universidade Federal da Bahia. Disponível em:

http://analisepoliticaemsaude.org/oaps/documento/noticias/1460471915570d086b9f2be. pdf. Acessado em: 01 de agosto de 2017.

SAUVÉ, L. Educação Ambiental: possibilidades e limitações. Revista Educação e pesquisa, São Paulo, v. 31, n. 2, p. 317-322, 2005a. Disponível em: http://www.revistas.usp.br/ep/article/view/27979. Acessado em: 07 de agosto de 2017.

SAÚVE, L. Uma cartografia das correntes em Educação Ambiental. In: SATO, M. (Org.); CARVALHO, I. (Org.): Educação Ambiental - pesquisa e desafios. Porto Alegre: Artmed, 2005b.

TAMAIO, I. O professor na construção do conceito de natureza: uma experiência de Educação Ambiental. São Paulo: Annablume/WWF, 2002. 
TORRES, J. R. Educação Ambiental crítico-transformadora e abordagem temática freireana. Tese de Doutorado em Educação Científica e Tecnológica, Centro de ciências biológicas: Universidade Federal de Santa Catarina, 2010. Disponível em: https://repositorio.ufsc.br/handle/123456789/93568. Acessado em: 07 de agosto de 2017.

TORRES, J.R; FERRARI, N; MAESTRELLI, S. R. P. Educação Ambiental críticotransformadora no contexto escolar: teoria e prática freireana. In: LOUREIRO, C. F. B; TORRES, J.R. (Orgs): Educação Ambiental: dialogando com Paulo Freire. $1^{\text {a }} \mathrm{Ed}$. São Paulo: Editora Cortez, 2014. 184 p.

TOZONI-REIS, M. F. C. Educação Ambiental: natureza, razão e história. 2. ed. Campinas - SP: Autores Associados, 2008. v. 1. 166 p.

TOZONI-REIS, M. F. C.; CAMPOS, L. M. L. A formação inicial de professores no fortalecimento da educação ambiental escolar: contribuições da pedagogia histórico crítica. In: LOUREIRO, C. F. B.; LAMOSA, R. A. Educação Ambiental no contexto escolar: Um balanço crítico da década da educação para o desenvolvimento sustentável. Rio de Janeiro: Quarter: CNPQ, 2015.

TOZONI-REIS, M.F.C; TALAMONI. J.L.B.; RUIZ, S.S.; NEVES, J. P.; TEIXEIRA, L.A; CASSINI, L.F.; FESTOZO, M.B.; JANKE, N.; MAIA, J.S.S.; SANTOS, H.M.S.; CRUZ, L. G.; MUNHOZ, R.H. A educação ambiental na escola básica: diretrizes para a divulgação dos conhecimentos científicos. Revista Pesquisa em Educação Ambiental, vol. 7, n. 1 - pp. 29-48, 2012. Disponível em: http://www.revistas.usp.br/pea/article/view/55941. Acessado em: 26 de fevereiro de 2018.

TRAJBER, R.; MENDONÇA, P. R. (Orgs.): O que fazem as escolas que dizem que fazem educação ambiental. Brasília: Secretaria de Educação Continuada, Alfabetização e Diversidade, 2006.

VEIGA, A.; AMORIM, E.; BLANCO, M. Um retrato da presença da educação ambiental no ensino fundamental brasileiro: o percurso de um processo acelerado de expansão. Brasília: INEP, 2005. 25 p. (Série Documental). Disponível em: https://www.faneesp.edu.br/site/documentos/publicacao6.pdf. Acessado em: 07 de agosto de 2017.

VENTURIERI, B; SANTANA, A. Concepções sobre Meio Ambiente de alunos do ensino fundamental em Belém-PA: estudo de caso com a E.E.E.F.M. Prof. Gomes Moreira Junior. Revista brasileira de Educação Ambiental, São Paulo, V. 11, No 1: 234-245, 2016. Disponível em: http://www.sbecotur.org.br/revbea/index.php/revbea/article/view/4752. Acessado em: 26 de fevereiro de 2018. 